SHORT REPORT

\title{
Emergence of methicillin resistant Staphylococcus aureus (MRSA) bacteraemia among children in England and Wales, 1990-2001
}

\author{
N Khairulddin, L Bishop, T L Lamagni, M Sharland, G Duckworth
}

Arch Dis Child 2004;89:378-379. doi: 10.1136/adc.2003.028712

Methicillin resistant Staphylococcus aureus (MRSA) is now a major cause of adult bacteraemia. All reports of Staphylococcus aureus bacteraemia to the Health Protection Agency were analysed from 1990 to 2001 . There were 376 cases of MRSA bacteraemia in children $<15$ years over this time. The proportion of Staphylococcus aureus bacteraemia due to MRSA increased steadily from $0.9 \%$ in 1990 to $13 \%$ in 2000. The proportion was higher in infants. MRSA bacteraemia is now a serious problem in children in England and Wales. More data on the risk factors for acquisition and spread of MRSA in children are required.

S taphylococcus aureus remains one of the most important causes of infection in children and adults. Methicillin resistant Staphylococcus aureus (MRSA) was first described in England in 1961 shortly after the introduction of methicillin. Epidemic strains appeared in England and Wales in the 1980s and 1990s, notably EMRSA-1, EMRSA-15, and EMRSA-16. ${ }^{1}$ The incidence of MRSA as a proportion of all $S$ aureus blood cultures rose from under $5 \%$ in 1991 to $42 \%$ in $2000 .^{2}$

The MRSA infection rate in children was believed to be much lower, although recent paediatric hospital based studies from New Zealand and Australia reported rates of $6 \%$ and $17 \%$ of methicillin resistant $S$ aureus bacteraemia. ${ }^{3}$ In this short report, we present the national data on the rate of MRSA bacteraemia among children less than 15 years in England and Wales from 1990 to 2001.

\section{PARTICIPANTS, METHODS, AND RESULTS}

Under the Health Protection Agency voluntary reporting scheme, microbiology laboratories throughout England and
Wales report all clinically relevant isolates to the Health Protection Agency Communicable Disease Surveillance Centre. Reports of $S$ aureus bacteraemia from LabBasel between 1990 and 2001 were analysed (table 1). No data were available on whether these were nosocomial or community acquired infections. Methicillin susceptibility data were not available for $17 \%$ of $S$ aureus reports over this period (16 801/98 755). Of the reports where methicillin susceptibility was available, 376 reports of MRSA bacteraemia among children were made between 1990 and 2001. Infants less than 12 months accounted for $53 \%$ of these cases. Both the absolute number and proportion of $S$ aureus bacteraemia reports due to MRSA increased steadily over this period, from a low of $4(0.9 \%)$ in 1990 to 77 (13.1\%) in 2000 (fig 1). The proportion of $S$ aureus bacteraemia due to MRSA increased most notably in infants, from 1\% in 1990 to $15 \%$ in 2000 and $13 \%$ in 2001 .

\section{DISCUSSION}

Our results show that since 1990, the incidence of $S$ aureus bacteraemia due to MRSA in children has increased substantially. Over the same time period the number of reports of methicillin sensitive $S$ aureus (MSSA) has remained largely static, for both infants and older children. It is probable these data represent an increase in MRSA from premature infants in neonatal units. MRSA outbreaks in neonatal intensive care units are well reported. ${ }^{5}$ The increasing proportion of MRSA bacteraemia in children is a cause for concern for both patients and clinicians. MRSA bacteraemia is associated with a higher mortality rate, longer hospital stay, and is a significant independent risk factor for death. ${ }^{6}$ Although some of these may be confounding factors, undoubtedly MRSA bacteraemia in infants may have serious sequelae. In addition, MRSA infections are usually resistant

Table 1 Number of reports of Staphylococcus aureus bacteraemia by age group (with percentage MRSA*), England and Wales, 1990-2001

\begin{tabular}{|c|c|c|c|c|c|c|c|c|c|c|c|c|}
\hline Age group & $\begin{array}{l}1990 \\
(\%)\end{array}$ & $\begin{array}{l}1991 \\
(\%)\end{array}$ & $\begin{array}{l}1992 \\
(\%)\end{array}$ & $\begin{array}{l}1993 \\
(\%)\end{array}$ & $\begin{array}{l}1994 \\
(\%)\end{array}$ & $\begin{array}{l}1995 \\
(\%)\end{array}$ & $\begin{array}{l}1996 \\
(\%)\end{array}$ & $\begin{array}{l}1997 \\
\text { (\%) }\end{array}$ & $\begin{array}{l}1998 \\
(\%)\end{array}$ & $\begin{array}{l}1999 \\
(\%)\end{array}$ & $\begin{array}{l}2000 \\
(\%)\end{array}$ & $\begin{array}{l}2001 \\
\text { (\%) }\end{array}$ \\
\hline$<1 \mathrm{mth}$ & $\begin{array}{l}140 \\
\text { (0) }\end{array}$ & $\begin{array}{l}174 \\
\text { (1) }\end{array}$ & $\begin{array}{l}184 \\
\text { (1) }\end{array}$ & 150 & 148 & $\begin{array}{l}177 \\
\text { (3) }\end{array}$ & $\begin{array}{l}161 \\
(5)\end{array}$ & $\begin{array}{l}174 \\
(10)\end{array}$ & $\begin{array}{l}171 \\
\text { (9) }\end{array}$ & $\begin{array}{l}198 \\
(14)\end{array}$ & $\begin{array}{l}181 \\
(19)\end{array}$ & $\begin{array}{l}199 \\
\text { (13) }\end{array}$ \\
\hline $1-11 \mathrm{mth}$ & 106 & $\begin{array}{l}127 \\
\text { (2) }\end{array}$ & $\begin{array}{l}114 \\
\text { (4) }\end{array}$ & $\begin{array}{l}138 \\
(2)\end{array}$ & $\begin{array}{l}97 \\
\text { (3) }\end{array}$ & $\begin{array}{l}110 \\
\text { (3) }\end{array}$ & $\begin{array}{l}152 \\
\text { (9) }\end{array}$ & $\begin{array}{l}145 \\
\text { (6) }\end{array}$ & 152 & 156 & 130 & 168 \\
\hline $1-4 y$ & $\begin{array}{l}125 \\
\text { (0) }\end{array}$ & $\begin{array}{l}131 \\
\text { (2) }\end{array}$ & $\begin{array}{l}129 \\
\text { (0) }\end{array}$ & $\begin{array}{l}134 \\
\text { (4) }\end{array}$ & $\begin{array}{l}144 \\
144 \\
\text { (3) }\end{array}$ & $\begin{array}{l}134 \\
\text { (2) }\end{array}$ & $\begin{array}{l}141 \\
145 \\
\text { (6) }\end{array}$ & $\begin{array}{l}101 \\
151 \\
(4)\end{array}$ & $\begin{array}{l}81 \\
177 \\
(8)\end{array}$ & $\begin{array}{l}13) \\
155 \\
(13)\end{array}$ & $\begin{array}{l}10) \\
158 \\
(13)\end{array}$ & $\begin{array}{l}(13) \\
211 \\
(10)\end{array}$ \\
\hline $5-9 y$ & $\begin{array}{l}95 \\
\text { (3) }\end{array}$ & $\begin{array}{l}94 \\
\text { (1) }\end{array}$ & $\begin{array}{l}86 \\
\text { (1) }\end{array}$ & $\begin{array}{l}102 \\
\text { (1) }\end{array}$ & $\begin{array}{l}93 \\
\text { (3) }\end{array}$ & $\begin{array}{l}83 \\
\text { (3) }\end{array}$ & $\begin{array}{l}78 \\
\text { (3) }\end{array}$ & $\begin{array}{l}135 \\
\text { (5) }\end{array}$ & $\begin{array}{l}114 \\
\text { (8) }\end{array}$ & $\begin{array}{l}117 \\
\text { (10) }\end{array}$ & $\begin{array}{l}115 \\
\text { (6) }\end{array}$ & $\begin{array}{l}103 \\
\text { (6) }\end{array}$ \\
\hline $10-14 y$ & $\begin{array}{l}103 \\
\text { (0) }\end{array}$ & $\begin{array}{l}119 \\
\text { (2) }\end{array}$ & $\begin{array}{l}103 \\
\text { (1) }\end{array}$ & $\begin{array}{l}116 \\
\text { (0) }\end{array}$ & $\begin{array}{l}126 \\
\text { (2) }\end{array}$ & $\begin{array}{l}116 \\
\text { (4) }\end{array}$ & $\begin{array}{l}84 \\
\text { (2) }\end{array}$ & $\begin{array}{l}108 \\
\text { (1) }\end{array}$ & $\begin{array}{l}124 \\
\text { (2) }\end{array}$ & $\begin{array}{l}103 \\
(5)\end{array}$ & $\begin{array}{l}134 \\
(15)\end{array}$ & $\begin{array}{l}139 \\
(6)\end{array}$ \\
\hline$>14 y$ & $\begin{array}{l}4026 \\
\text { (2) }\end{array}$ & $\begin{array}{l}4105 \\
\text { (2) }\end{array}$ & $\begin{array}{l}4183 \\
\text { (3) }\end{array}$ & $\begin{array}{l}4808 \\
\text { (4) }\end{array}$ & $\begin{array}{l}5160 \\
(9)\end{array}$ & $\begin{array}{l}5806 \\
(15)\end{array}$ & $\begin{array}{l}7103 \\
\text { (23) }\end{array}$ & $\begin{array}{l}8652 \\
(32)\end{array}$ & $\begin{array}{l}9377 \\
(37)\end{array}$ & $\begin{array}{l}9955 \\
\text { (39) }\end{array}$ & $\begin{array}{l}11427 \\
(43)\end{array}$ & $\begin{array}{l}12040 \\
\text { (45) }\end{array}$ \\
\hline
\end{tabular}

*As a percentage of total Staphylococcus aureus bacteraemia reports with methicillin susceptibility information available. 


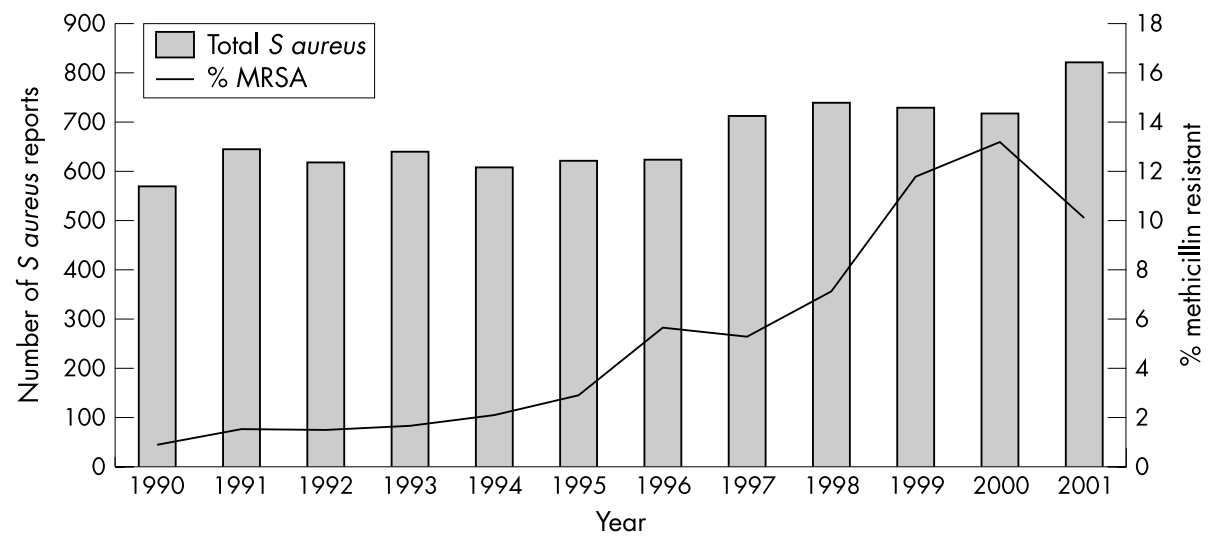

Figure 1 Staphylococcus aureus bacteraemia reports in children ( $<15$ years) and methicillin susceptibility (as a percentage of all. Staphylococcus aureus bacteraemia reports with methicillin susceptibility data available); England and Wales, 1990-2001.

to multiple antibiotics. The glycopeptides, vancomycin and teicoplanin, are currently the antibiotics of choice, but are not as effective against methicillin susceptible strains of $S$ aureus as anti-staphylococcal $\beta$-lactams, and require intravenous therapy. Furthermore, extensive use of vancomycin may have contributed to the emergence of vancomycin resistant enterococci, and more recently, vancomycin resistant $S$ aureus (VRSA).

Although the rate of MRSA bacteraemia in children is not yet as high as that in adults, active steps need to be taken to ensure that the problem of MRSA will not escalate further in children to adult levels. We recommend an urgent national review identifying the risk factors for MRSA acquisition on neonatal and paediatric units, and the infection control measures in place. In summary, our data suggest that MRSA is becoming an increasing problem among children in England and Wales.

\section{Authors' affiliations}

N Khairulddin, M Sharland, Paediatric Infectious Disease Unit, St George's Hospital, London, UK
L Bishop, T L Lamagni, G Duckworth, Division of Healthcare-Associated Infection and Antimicrobial Resistance, Health Protection Agency Communicable Diseases Surveillance Centre, London, UK

Correspondence to: Dr M Sharland, Paediatric Infectious Disease Unit, St George's Hospital, London, UK; mike.sharland@stgeorges.nhs.uk

Accepted 18 June 2003

\section{REFERENCES}

1 CDSC. Epidemic methicillin resistant Staphylococcus aureus. Commun Dis Rep CDR Wkly 1995;5:165-8.

2 PHLS Communicable Diseases Surveillance Centre. Chapter 9: Staphylococcus aureus. 1999/2000 review of communicable diseases, England and Wales. London: PHLS, 2001.

3 Hill PC, Wong CG, Voss LM, et al. Prospective study of 125 cases of Staphylococcus aureus bacteremia in children in New Zealand. Pediatr Infect Dis J 2001; 20:868-73.

4 Suryati BA, Watson M. Staphylococcus aureus bacteraemia in children: a 5-year retrospective review. J Paediatr Child Health 2002;38:290-4.

5 Andersen BM, Lindemann R, Bergh K, et al. Spread of methicillin-resistant Staphylococcus aureus in a neonatal intensive care unit associated with understaffing, overcrowding and mixing of patients. J Hosp Infect 2002;50:18-24.

6 Cosgrove SE, Sakoulas G, Perencevich EN, et al. Comparison of mortality associated with methicillin-resistant and methicillin-susceptible Staphylococcus aureus bacteremia; a meta-analysis. Clin Infect Dis 2003;36:53-9. 